\title{
Lymphangitis carcinomatosa of a cutaneous squamous cell carcinoma
}

\author{
Marloes Sophia van Kester, Roel Erik Genders, Koen Dirk Quint
}

Department of Dermatology, LUMC, Leiden, The Netherlands

\section{Correspondence to \\ Dr Koen Dirk Quint, \\ k.d.quint@lumc.nl}

Accepted 28 January 2018

\section{DESCRIPTION}

An 83-year-old woman presented with erythema, papules and nodules on the left upper arm (figure 1A). She was treated with antibiotics by her general practitioner, with no disease response. Eight months earlier a $2.5 \mathrm{~cm}$ poorly differentiated primary cutaneous squamous cell carcinoma of the left preauricular area, with metastases to the regional lymph nodes, was staged T2N2M0 (tumour, node, metastases). She was treated with radical tumour resection, parotidectomy, and levels 2, 3 and 5 lymph node dissection, followed by postoperative radiotherapy. A total body skin examination was performed. On the left upper arm and adjacent to the axillary sulcus, a poor demarcated area of erythema with papules and nodules was noted. There were no signs of recurrent disease in the head and neck area, and no suspicious lesions elsewhere. Biopsies were taken from nodular and papular lesions on the upper arm.

Histology showed poorly differentiated squamous cell carcinoma in the dermis without continuity to the epidermis (figure $1 \mathrm{~B}$ ) and strongly positive keratin staining (figure 1C), thereby confirming the diagnosis of cutaneous metastasis of a primary cutaneous squamous cell carcinoma. Furthermore positron emission tomography (PET)-CT scan shows increased metabolism in the left upper arm, lymph nodes suspected for

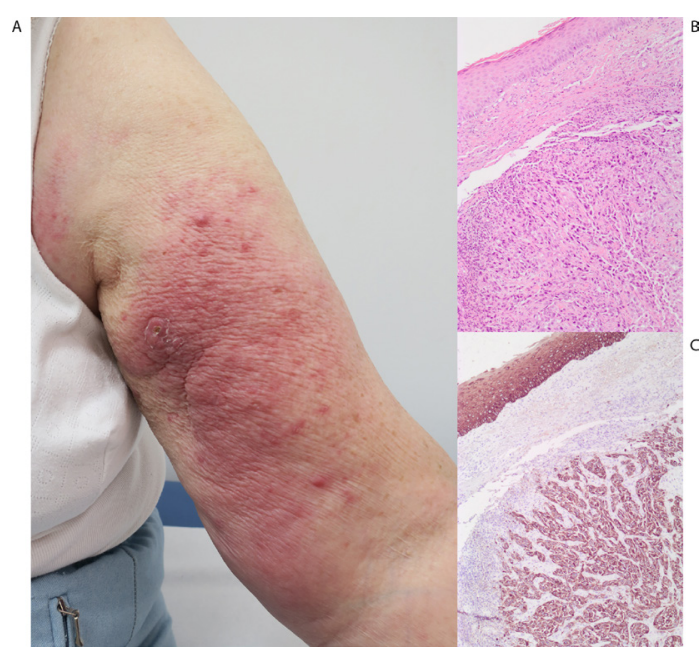

Figure 1 (A) Clinical image of the skin lesion showing erythema with papules and nodules on the left upper arm and adjacent to the axillary sulcus. (B) HE staining (100x magnification) of a $3 \mathrm{~mm}$ biopsy of the left arm showing atypical cells in the dermis without connection with the epidermis. (C) Keratin staining (100x magnification) confirming a squamous cell origin.

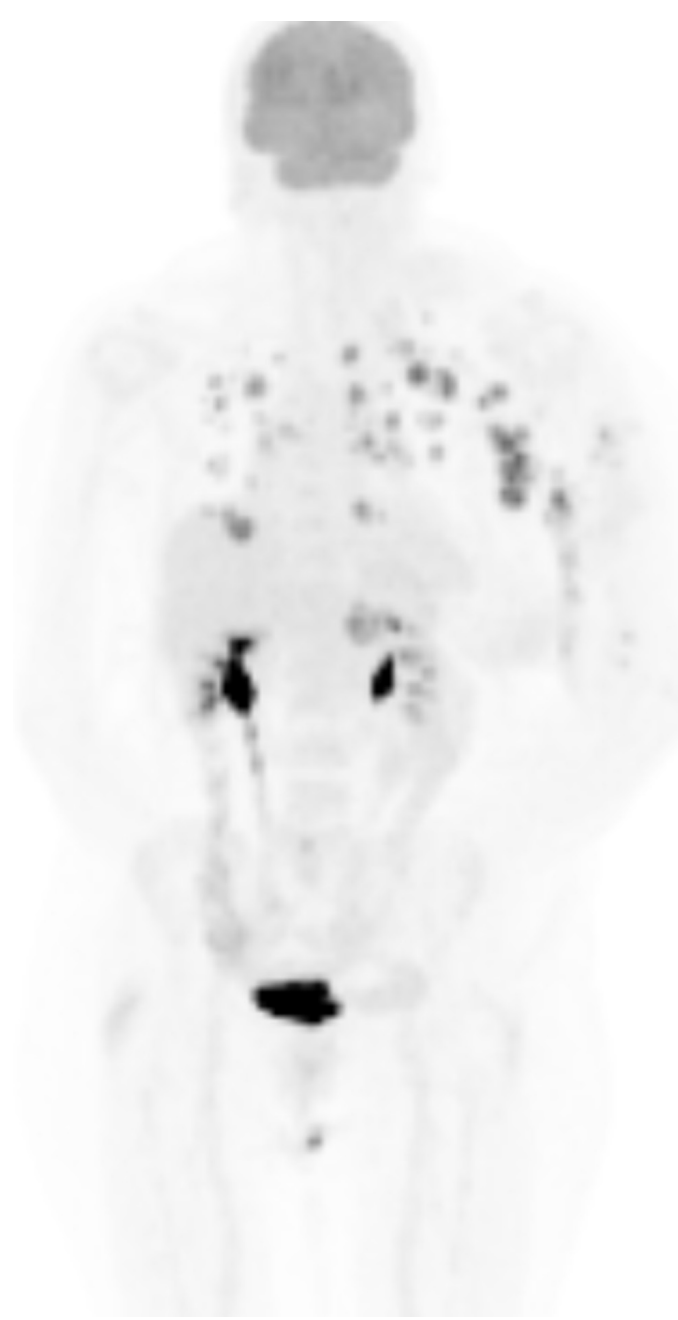

Figure 2 Positron emission tomography-CT scan reveals increased metabolism in the left upper arm, lymph node metastases in the left axilla, elbow, delta pectoral, bihilar and mediastinal regions, and multiple lung metastases.

metastases in the left axilla, elbow, delta pectoral, bihilar and mediastinal regions, and multiple lung lesions (figure 2).

Previously the primary cutaneous squamous cell carcinoma had already metastasised to the regional lymph nodes demonstrating behaviour of a high-risk tumour. The overall risk for nodal metastasis of cutaneous squamous cell carcinoma is $3.7 \%-5.2 \% .^{1}$ Several risk factors for metastasis were identified in the resection of the primary tumour: diameter $>2 \mathrm{~cm}$, poor differentiation and $6 \mathrm{~mm}$ invasion depth. ${ }^{12}$

Remarkably, no locoregional disease recurrence was noted clinically or demonstrated by PET-CT 


\section{Learning points}

- High risk cutaneous squamous cell carcinoma can develop lymphangitis carcinomatosa.

- Lymphangitis carcinomatosa can occur beyond the draining lymph node basin of the primary tumour.

scan or ultrasound. Most likely, the tumour spread further through the lymphatic system, eventually demonstrating in the small lymphatic vessels of the skin, presenting the clinical image of a lymphangitis carcinomatosa. Lymphangitis carcinomatosa has been previously described after removal of a lymphatically invasive primary cutaneous squamous cell carcinoma in a renal transplant recipient. ${ }^{3}$ Thus far, lymphangitis carcinomatosa due to cutaneous squamous cell carcinoma outside tumour-draining lymph node basin and as primary demonstration of recurrent disease has not been described.
Contributors MSvK: patient care and clinical diagnosis, writing the manuscript and final approval of the version to be published. REG: patient care and clinical diagnosis, critically reviewing the manuscript, and final approval of the version to be published. KDQ: patient care and clinical diagnosis, histology, critically reviewing the manuscript, and final approval of the version to be published.

Competing interests None declared.

Patient consent Obtained.

Provenance and peer review Not commissioned; externally peer reviewed.

(c) BMJ Publishing Group Ltd (unless otherwise stated in the text of the article) 2018. All rights reserved. No commercial use is permitted unless otherwise expressly granted.

\section{REFERENCES}

1 Thompson AK, Kelley BF, Prokop LJ, et al. Risk factors for cutaneous squamous cell carcinoma recurrence, metastasis, and disease-specific death: A systematic review and meta-analysis. JAMA Dermatol 2016;152:419-28.

2 Brougham ND, Tan ST. The incidence and risk factors of metastasis for cutaneous squamous cell carcinoma--implications on the T-classification system. J Surg Oncol 2014;110:876-82.

3 Lorentzen HF. Carcinoma "en Cuirasse" from cutaneous squamous cell carcinoma in a renal transplant patient. Transplantation 2008;85:1065-6.

Copyright 2018 BMJ Publishing Group. All rights reserved. For permission to reuse any of this content visit http://group.bmj.com/group/rights-licensing/permissions.

BMJ Case Report Fellows may re-use this article for personal use and teaching without any further permission.

Become a Fellow of BMJ Case Reports today and you can:

- Submit as many cases as you like

- Enjoy fast sympathetic peer review and rapid publication of accepted articles

- Access all the published articles

- Re-use any of the published material for personal use and teaching without further permission

For information on Institutional Fellowships contact consortiasales@bmjgroup.com

Visit casereports.bmj.com for more articles like this and to become a Fellow 